\title{
Perspectives
}

\section{The Place of Culture in Teaching English as an International Language (EIL)}

\section{Hideo Horibe \\ Hiroshima Institute of Technology}

In the conventional ELT paradigm it has often been said that teaching English cannot be separated from teaching the culture of its native speakers. But in the paradigm of English as an International Language (EIL), which focuses on the functions of English as a means of communication among people from various linguistic and cultural backgrounds, the traditional view of culture must be thoroughly reconsidered. Attempting to define the place of culture in EIL, this article presents a new conceptual framework consisting of three kinds of culture: (1) culture as social custom, (2) culture in the pragmatic sense, and (3) culture in the semantic sense. Based upon this classification, the article attempts to clarify how culture should be understood and dealt with in the EIL perspective, and proposes what cultural factors should be incorporated into the classroom, both in the general ELT context and in the specific context of Japanese English education.

従来の英語教育の理論的枠組みにおいては、英語を教えることはその母語話者の文化を教 えることと切り離せないとよく言われてきた。しかし、多様な言語的・文化的背景を持つ人々の 間での意思疎通の手段としての英語の機能を重視する「国際語としての英語」(EIL)という理論 的枠組みにおいては、このような伝統的文化観は根本から見直さなければならないだろう。EIL における文化の位置を見定めるための試みとして、本稿は「社会習慣としての文化」「語用論的 意味における文化」「意味論的意味における文化」の 3 種類からなる新しい文化概念を提起す る。この三分法に基づき、一般的な英語教育のコンテクストと日本の英語教育という特定のコン テクストの双方において、EILの観点から文化をどのように理解し、取り扱うべきかを明らかに し、どのような文化的要素を授業に取り入れていくべきかについて具体的な提案をする。

JALT Journal, Vol. 30, No. 2, November, 2008 


\section{Introduction $^{1}$}

It has generally been accepted that language and culture are inextricably interrelated with each other. Such an idea can be traced to the 'Weltanshauung' (worldview) Hypothesis, formulated by a German philosopher, Karl Wilhelm von Humboldt (1767-1835), which postulates that human thought cannot exist without language, and that the diversity of human language is a diversity of ways of looking at the world. Humboldt's notion of linguistic relativity was inherited by American anthropologists Edward Sapir (1884-1939) and Benjamin Lee Whorf (1897-1941). Their view, known as the Sapir-Whorf Hypothesis, centers upon the idea that culture determines or influences language, which in turn determines or influences ways humans categorize their thoughts about the world and their experiences in it.

Drawing directly or indirectly on the Sapir-Whorf Hypothesis, many ELT professionals have emphasized the essential relationship between language and culture and the importance of incorporating culture into language teaching. For example, Lado (1964) states that "a language is part of the culture of a people and the chief means by which the members of a society communicate" (p. 23), and defines the goal of foreign language teaching as "the ability to use it, understanding its meanings and connotations in terms of the target language and culture, and the ability to understand the speech and writing of natives of the target culture in terms of their meanings" (p. 25). Chastain (1976) also states that "in the ideal second-language class the teaching of culture is an integral, organized component of the course content," noting that in such a course the students "expect to gain some degree of functional ability in the culture as well as in the language" (p. 383). Crawford-Lange and Lange (1984) pointedly maintain that "to study language without studying the culture of native speakers of the language is a lifeless endeavor" (p. 140).

Nowadays, however, a lot of people pay attention to the global spread of English and its extensive use as a lingua franca, and in many non-English-speaking countries English is taught and learned as an international language rather than as the Anglo-American language. It is not easy to define what EIL means, but according to Smith (1987), the essence of the concept can be summarized as follows: (1) English is a means of communication among various people from various linguistic and cultural backgrounds; (2) English is the property of its users, native and nonnative; (3) Non-native speakers do not have to use English the same way native speakers do. If such a concept is accepted, simple and direct connections 
between English and its native-speaker cultures can no longer be presupposed, and it is a logical consequence that the traditional view of culture in language teaching must be thoroughly reexamined.

\section{Is culture irrelevant in EIL?}

One extreme view is that there is no need to include cultural factors in EIL. Some ELT professionals regard English in the international context as a culture-free or culturally-neutral language. For instance, González emphasizes that in the teaching of English as an International Auxiliary Language (EIAL), "English is deracinated or uprooted from its original cultural soil; only special registers of science and technology, business and geopolitics are used" (cited in McKay 2002, p. 84). Quirk (1982) considers Nuclear English "culture-free as calculus, with no literary, aesthetic, emotional aspirations" (p. 43). Kunihiro (1999) compares English to Morse Code, though he acknowledges that this is an exaggeration.

However, this article does not take the position that culture is irrelevant in EIL. A language can never be culture-free in its essential sense as long as it is a natural language. A natural language is a historical entity, and so the English language, however geographically spread it may be, is still bound to the long socio-cultural history of the nations from which the language originated. It is also true that as a language is actually used by various people, it is inevitably associated with their ways of living and thinking. The acculturation of English means that English is no longer bound to Anglo-American culture exclusively, not that English is now being used or can be used in a cultural vacuum. Kachru (1992) emphasizes that "English represents a repertoire of cultures, not a monolithic culture" (p. 362); in essence, the spread of English has entailed the diversification of culture associated with the language. Then, which culture or whose culture should be dealt with in the EIL classroom is an important question.

\section{Proposing a new conceptual framework of culture}

One fundamental problem in discussing culture in ELT is the ambiguity of the term 'culture.' Culture, which Hall (1973) calls a "muddied concept" (p. 20), is notoriously difficult to define. It covers an extremely wide range of ideas, thoughts, beliefs, views, values, manners, customs, and institutions. Even within the teaching of language, the term culture has diverse definitions (e.g. Hammerly 1982; Byram \& Risager 1999, Ito 
2002), and so it is highly possible that when several ELT professionals are talking about culture, each of them is referring to an entirely different sort of culture.

A well-known classification of culture is the dichotomy of high culture and anthropological culture, and the same idea is often expressed by the difference between "large C" culture and "small c" culture. Given this dichotomy, most teachers interested in EIL would agree that culture in the classroom should refer mainly to the latter. But this is still too broad.

In this article, modifying the categorization presented by Adaskou, Britten, and Fahsi $(1990)^{2}$, I propose a conceptual framework in which culture is divided into three kinds. They are:

- culture as social custom

- culture in the pragmatic sense

- culture in the semantic sense.

Though many cultural factors are omitted, this framework seems to serve the practical purpose of clarifying the place of culture in teaching English as an international language. I will next briefly define each of the three kinds of culture, place it in the EIL paradigm, and put forth my proposals of how culture should be incorporated into the EIL classroom, with specific attention to the ELT context in Japan.

\section{Culture as social custom}

Culture as social custom covers a wide spectrum of things related to human life and society. It is represented by ways, styles, and customs of daily life, and by various commodities such as houses, food, and clothes involved in everyday life. For instance, kimchi and chima chogori are good examples of Korean culture. Culture in this sense is also represented by social customs or institutions such as traditional celebrations or festivals like Thanksgiving Day and Halloween in America. When one casually says 'Korean culture' or 'American culture,' it usually means this sort of culture.

In the conventional ELT paradigm, culture in this sense means AngloAmerican culture. It has been taken for granted that when learning English one is justly learning about British and American life and society. However, this is not the case in EIL. As English is used extensively by a countless number of people outside of its original cultural sphere, it would be unreasonable to think that cultural content in EIL must directly 
concern Anglo-American culture. In the EIL paradigm culture as a social custom does not have to be relevant to traditional English-speaking nations at all, and any cultural theme or topic can be included, provided that the choice can be justified on pedagogical grounds.

Thus, the appropriate cultural content can greatly vary, and its choice essentially depends upon the purpose of each teaching situation. EIL teachers must be sensitive and flexible to learners' needs and interests, and they must be careful about imbuing the English language with a national culture which may not be central to learners' purposes for learning the language (Bowers 1999; Prodromou 1992). It would be ideal for individual learners to be able to choose their optimal cultural content. For example, in a class of Korean businessmen soon to be assigned to Singapore, the culture which would be emphasized would be that of Singapore.

\section{Culture as social custom in the Japanese context}

In Japan, English education was vigorously promoted with the aim of modernization and industrialization in the late $19^{\text {th }}$ century, and for a long time, the main purpose of learning English was to absorb what was considered to be superior, advanced English culture and civilization. Therefore, the tendency to think that to learn English means to learn about the Anglo-Americans has been quite strong. For instance, the guidelines issued by the Ministry of Education in 1947 specified that one of the objectives of teaching English was "to get to know about Englishspeaking nations, especially about their manners and customs and their daily life." 3 In particular, American life styles, customs, and various other Americana constituted cultural contents of teaching materials. This orientation can be observed typically in Jack and Betty, published in 1948. This was the leading textbook for junior high school in the postwar era, which centered on the daily life of a white, middle-class American family living in the suburbs of Chicago. This textbook seems to symbolize the postwar Japanese longing for rich, advanced and democratic American life. For those who perceived such longing as the motivation to learn English, the language was inseparable from American daily-life culture, and this can be said of many English learners even in today's Japan.

While the tendency is still notable in many aspects of ELT in Japan, there have been certain changes in recent years. Around 1980, junior high school textbooks began to deal with the Third World and Southeast Asia from a cross-cultural viewpoint. The present guidelines by the Ministry of Education suggest that textbooks should cover "topics that relate to 
the daily lives, manners and customs, stories, geography, history, etc. of Japanese people and the peoples of the world, focusing on countries that use English," ${ }^{4}$ and actually high school textbooks today include many different societies and cultures in the world along with Japanese society and culture. University-level textbooks, which used to center around British and American literature, now covers diverse cultural topics and contents including global issues and current affairs around the world.

Fundamentally, the concept of EIL supports this trend, but it is hard to say that a clear direction is shared among Japanese ELT professionals. Some emphasize the importance of incorporating Japanese culture from the viewpoint of explaining it to foreigners (e. g. Suzuki 1999), and this is practiced in many textbooks. Legitimate as the idea may be, there is a concern that the typical lesson taught by a Japanese teacher focusing on Japanese culture tends to be the work of a self-complacent monologist in which otherness is not involved. I am also concerned that the use of various world cultures in English class often stays at a quite superficial level, and is likely to end up with presenting an arbitrary array of world cultures and customs. Even worse, it may lead to an oversimplified view of English as a panacea for international understanding.

In this light, I propose that more attention should be paid to Asian Englishes and cultures associated with them. In view of English as an Asian language, Japanese EIL teachers may incorporate into the classroom the questions of how English has been used in Asian countries, and what influences, either positive or negative, it has exerted on local cultures and identities. In consideration of the fact that Japanese people have more opportunities to communicate in English with Asians than with AngloAmerican native speakers, these cultural topics will stimulate students to reconsider raisons d'être of English education, and give them a new incentive to learn the language.

\section{Culture in the pragmatic sense}

Crystal (2003) defines pragmatics as "the study of language from the point of view of the users, especially of the choices they make, the constraints they encounter in using language in social interaction, and the effects their use of language has on the other participants in an act of communication" (p. 364). Based on this, this article defines culture in the pragmatic sense as "culture accompanied with the actual use of language, especially cultural choices, constraints, and effects in an act of interpersonal communication." 
In the traditional ELT paradigm, learners are required or expected to conform to culture in the pragmatic sense of native speakers, so that they can appropriately communicate with them or preempt misunderstanding. They need to get acquainted with and hopefully internalize pragmatic norms and conversational patterns of native speakers in greeting, thanking, complimenting, apologizing, complaining, requesting, turn-taking and so forth. They are also supposed to learn and use native speakers' non-verbal communication cues such as making eye contact or maintaining a certain distance from the interlocutor.

In the EIL paradigm, however, such conformism is no longer appropriate. On the assumption that English is associated with diverse cultures, it is not valid to require all English speakers to follow and adopt the norms and patterns of native speakers. Expecting to speak with various English speakers, ideally EIL learners need to know various norms and patterns. Needless to say, it is very difficult to get familiar with numerous pragmatic variations. Therefore, the main goal of teaching this kind of culture should be to develop flexible, generous, and empathetic attitudes toward diverse pragmatic norms of diverse English speakers in the world. It means to cultivate the ability to be aware of cultural differences in a nonjudgmental way, and use the awareness for better communication. Byram (1997) and Kramsch (1998) call a speaker with such ability an "intercultural speaker." This should be a key concept of teaching pragmatics in the EIL paradigm.

In this perspective, it is important for EIL teachers to pay attention to research in the new academic field of intercultural pragmatics, represented by the journal Intercultural Pragmatics which started in 2004. EIL teachers are now expected to be well aware of issues and problems related to language use and communication in which different cultures are involved. As a classroom practice, they need to learn and teach communicative strategies to accommodate different sociolinguistic norms and a range of repair strategies which can be used in the face of misunderstanding (Kirkpatrick 2007). It will also be meaningful to provide learners with opportunities to interact with English speakers from various backgrounds, and to encourage them to "act as amateur ethnographers and collect their own examples of speech acts" (Judd 1999, p. 156). It is expected that cooperative cross-cultural communication activities with strategic consciousness will help learners become aware of pragmatic differences and similarities, and manage to make their own informed choices, depending upon the situation or the interlocutor. 


\section{Culture in the pragmatic sense in the Japanese context}

In Japanese English education, the premise that non-native speakers should conform to native speakers' norms seems to have been unquestioned, and pragmatic variations in view of communication between non-native speakers have not yet been taken into account. For instance, Yokomori (1998) analyzed eight high school textbooks of oral communication and identified the characters appearing in these textbooks. According to him, $43 \%$ of the characters were native speakers, and $48 \%$ were Japanese. This indicates that most model dialogues are between native speakers and Japanese. Moreover, many articles about pragmatics written by Japanese researchers usually focus on advice as to how to communicate smoothly and appropriately with native speakers. They often state that pragmatic transfer from L1 will cause misunderstandings, and sometimes grave offense, implying that non-native speakers are always responsible for such communication problems. In addition, according to some observers, Japanese students in the classroom are often told to make direct eye contact, avoid scratching hair to control embarrassment, and to point a forefinger to the chest, not to the nose when saying ' $\mathrm{I}$ ' or 'me' (Honna \& Takeshita 1998).

To be sure, it is necessary to teach basic pragmatic norms of native speakers, but teachers must be careful about imposing them on students. Moreover, teachers should have students realize that there are pragmatic variations in non-native speaker Englishes, and that intercultural speakers need to learn to cope flexibly with such variations. In this light, it is worth noting that Asians at large share culture in the pragmatic sense. For instance, modest or circumlocutory expressions, which are often said to cause misunderstanding in English, may sound natural among Asians. Kawahara (2002) points out that Filipinos often use 'I'll try' as an indirect way to say 'No,' or 'No, I can't do that.' Also, compliment rejections seem to be widely shared among Asians. As the response to a compliment, according to Honna (2006), 'I'm not that good. You've overpraised me' is heard more frequently among speakers of English in China than 'Thank you.' These instances imply that Asian English speakers may be able to communicate smoothly and comfortably with each other based upon their traditional communication patterns. As it is natural that the more frequently English is used among Asians, the more Asian communication patterns will seep into their Englishes, some pragmatic characteristics of Asian English speakers should be recognized not as something negative which is deviant from norms but as something legitimate which reflects Asian culture. Such recognition will encourage Japanese people to use 
English more actively as part of their own linguistic repertoire. A pedagogical implication here is that there should be more Asian English speakers engaged in ELT in Japan, and that teacher recruitment policy such as in the JET Programme should be reconsidered in this perspective.

\section{Culture in the semantic sense}

Humans shape the perception of reality through categorizing the world and their experiences by language, and the way a language cuts up the semantic universe reflects culture's interests and concerns. Thus, culture in the semantic sense can be defined as culture embedded in the semantic system of a language.

There are a number of examples to show that culture is embedded in the lexical structure of a language. A well-known example is the multiplicity of Inuit words for snow, which is said to reflect the importance of snow in Inuit culture. In comparing English with Japanese, a simple, everyday example can be found in the lexical structure related to siblings. There is no word in Japanese equivalent to the word 'brother' in English, because it must always be clarified in Japanese whether the referent is 'younger brother' or 'elder brother.' In addition, when we compare Japanese with Korean, we notice that in Korean there is no single word for 'elder brother': there are two distinct words referring to 'elder brother of a [younger] brother' and 'elder brother of a [younger] sister.' As Seelye (1984) succinctly says, "Perceptions of colors, kinship relations, space and time, all differ from language to language and from culture to culture" (p. 22). Strictly speaking, the meaning of a word is determined only in the linguistic and cultural system in which the word exists, and therefore, "one-to-one equivalences can rarely be established between words and expressions in two languages" (Rivers 1981, p. 318). In this way, studying the meaning of a word in another language nearly always leads to discovery of different views, perceptions and thoughts.

No matter how internationalized English may be, the semantic features of English words are so deeply embedded that they cannot easily be subject to change, and in this sense native-speaker culture should be respected as the reference source for various users of English to communicate accurately with one another. If learners have little awareness of this kind of culture and arbitrarily transfer their L1 semantic system, the international intelligibility can be seriously damaged. It is true that even the meanings of words can go through changes over time as they are used by different speakers in the world, but changes should be seen not only as 
peripheral but also as referable and traceable back to the semantic system of native-speaker English.

\section{Culture in the semantic sense in the Japanese context}

Culture in the semantic sense is an essential component in any language teaching situation, and awareness-raising of this kind of culture seems especially important for Japanese students because of the vast difference between English and Japanese in their semantic structures. There can be several ways to raise such awareness, but I emphasize that translation exercise serves the purpose well because it naturally requires flexible search for the most suitable words to convey accurately what is meant in the original test. In conveying the meaning of such words as 'mind,' 'heart,' 'soul' or 'spirit' into Japanese, translators must be very sensitive to the semantic field of each word. Similarly, one will easily notice that heavily culturally-loaded concepts such as 'giri' (義理) and 'on' (恩) or 'wabi' (侘び) and 'sabi' (寂び) are awfully difficult to translate into English. Furthermore, it is important to be aware that many simple everyday words are deeply related to culture. For example, the simple Japanese word 'koshi' (腰) is a formidable one for a translator. While it basically means 'the lower back part of our body,' it has a large semantic field, and in English it can be translated as 'waist,' 'hip,' 'back,' 'lumbar' or even 'knees,' depending upon the context. There are also a number of expressions using 'koshi' metaphorically, like 'koshi ga hikui (humble, or feigning humility)' or 'koshi ga kudakeru (become dispirited).' These expressions are utterly impossible to translate word by word, and must be rephrased entirely in order to make sense in English. Perhaps the extensive use of 'koshi' in Japanese is related to the traditional life style of wearing kimono and sitting on tatami mats (Ando 1986). Thus, in translating from English to Japanese, and vice versa, learners are often required to think in depth of culture embedded in words, expanding their insight into the essential relationship between language and culture. I propose that translation exercise should be revaluated in this perspective.

\section{Conclusions}

In this article, I have proposed a threefold classification of culture to determine the place of culture in EIL. The central argument is that in dealing with culture as a social custom and culture in the pragmatic sense, the diversity of culture associated with the worldwide spread of English should be taken into full consideration, while in dealing with culture in 
the semantic sense, native-speaker culture should be respected in order to carry out precise communication.

Despite the emphasis on the value and functions of English as an international language in educational settings, it seems that the implications of the acculturation of English have not yet been fully reflected in the classroom. In Japan especially, in the name of 'kokusai-rikai' (international understanding) or 'ibunka-rikai' (cross-cultural understanding), culture is regarded as an integral part of English education, but enough consideration does not seem to be given to the implications of the extensive international use of English, and the term 'culture' is often used quite carelessly and vaguely. Particularly there often seems to be confusion between the idea of teaching Anglo-American culture in English and the idea of teaching various cultures in the world through English. If we are to move toward EIL, the complicated relationship between language and culture must be examined in a new light. Without such examination, attempts to teach culture could easily fall prey to stereotyping or lead to the inappropriate dissemination of specific cultural values. It is hoped that my arguments in this article can be of service to the consideration of the place of culture in teaching English as an international language.

Hideo Horibe is a professor at Hiroshima Institute of Technology. His research interests include language policy, language education policy, and English as an international language.

\section{Notes}

1. This article is a revised version of a plenary address given at the annual International Conference of the Korea Association of Teachers of English at Gyeongin National University of Education on July 6, 2007.

2. Adaskou, Britten and Fahsi (1990) present four kinds of culture: 'culture in the aesthetic sense,' 'culture in the sociological sense,' 'culture in the pragmatic sense' and 'culture in the semantic sense.' I deleted the first one because it is equivalent to "large $C$ " culture, and I changed 'sociological sense' to '... as a social custom' because the latter seems more suitable in this article.

3. http:/ / www.nicer.go.jp/guideline/ old / s22ejl/ chap1.htm

4. http:/ / www.mext.go.jp/english/shotou/030301.htm 


\section{References}

Adaskou, K., Britten, D., \& Fahsi, B. (1990). Design decisions on the cultural content of a secondary English course for Morocco. ELT Journal, 44(1), 3-10.

Ando, S. (1986). Eigo no ronri: Nihongo no ronnri [The logic of English: The logic of Japanese]. Tokyo: Taishukan-shoten.

Bowers, R. (1999). Whose culture does the English language learner want? Two case studies. In C. Gnutzmann (Ed.), Teaching and learning English as a global language: Native and non-native perspectives (pp. 221-244). Túbingen: Stauffenburg Verlag.

Byram, M. (1997). Teaching and assessing intercultural communicative competence. Clevedon, North Somerset: Multilingual Matters Ltd.

Byram, M. \& Risager, K. (1999). Language teachers, politics and cultures. Clevedon, North Somerset: Multilingual Matters Ltd.

Chastain, K. (1976). Developing second-language skills: Theory to practice ( $2^{\text {nd }}$ edition). Chicago: Rand McNally College Publishing Company.

Crawford-Lange, L. M. \& Lange, D. L. (1984). Doing the unthinkable in the second language classroom: A process for the integration of language and culture. In T. V. Higgs (Ed.), Teaching for proficiency: The organizing principle (pp. 139-177). Lincolnwood, IL: National Textbook Company.

Crystal, D. (2003). A dictionary of linguistics $\mathcal{E}$ phonetics (5 ${ }^{\text {th }}$ edition). Oxford: Blackwell Publishing.

Hall, E. T. (1973). The silent language. New York: Anchor Books.

Hammerly, H. (1982). Synthesis in second language teaching. Blaine, WA: Second Language Publications.

Honna, N. (2006). East Asian Englishes. In B. B. Kachru, Y. Kachru and C. L. Nelson (Eds.), The handbook of world Englishes (pp. 114-129). Malden: Blackwell Publishing.

Honna, N. \& Takeshita, Y. (1998). On Japan's propensity for native speaker English: A change in sight. Asian Englishes, 1(1), 117-137.

Ito, H. (2002). A new framework of culture teaching for teaching English as a global language. RELC Journal, 33(2), 36-57.

Judd, E. L. (1999). Some issues in the teaching of pragmatic competence. In E. Hinkel (Ed.), Culture in second language teaching and learning (pp. 152-166). Cambridge: Cambridge University Press.

Kachru, B. B. (1992). Teaching world Englishes. In B. B. Kachru (Ed.), The Other tongue: English across cultures (2 ${ }^{\text {nd }}$ edition) (pp. 355-365). Urbana and Chicago: University of Illinois Press.

Kawahara, T. (2002). Republic of the Phillipines. In N. Honna (Ed.), Ajia no saishin eigo jijyo (The encyclopedia of the English language situation in Asia) (pp. 199-213). Tokyo: Taishukan-shoten. 
Kirkpatrick, A. (2007). World Englishes: Implications for international communication and English language teaching. Cambridge: Cambridge University Press.

Kramsch, C. (1998). The privilege of the intercultural speaker. In M. Byram \& M. Fleming (Eds.), Language learning in intercultural perspective: Approaches through drama and ethnography (pp. 16-31).Cambridge: Cambridge University Press,

Kunihiro, M. (1999). Messages from the persons of this month (interview). Jijieigo Kenkyu, 53(12). Tokyo: Kenkyusha.

Lado, R. (1964). Language teaching: A scientific approach. New York: McGraw-Hill, Inc.

McKay, S. L. (2002). English as an international language: Rethinking goals and approaches. Oxford: Oxford University Press.

Prodromou, L. (1992). What culture? which culture? Cross-cultural factors in language learning. ELT Journal, 46(1), 39-50.

Quirk, R. (1982). Style and communication in the English language, London: Edward Arnold.

Rivers, W. M. ([1968] 1981). Teaching foreign-language skills ( $2^{\text {nd }}$ edition). Chicago and London: The University of Chicago Press.

Seelye, H. N. (1984). Teaching culture: Strategies for intercultural communication. Lincolnwood, IL: National Textbook Company.

Smith, L. E. (Ed.) (1987). Discourse across cultures. New York: Prentice Hall.

Suzuki, T. (1999). Nihonjin wa naze eigo ga dekinaika [Why are the Japanese poor at English?]. Tokyo: Iwanami-shoten.

Yokomori, S. (1998). An analysis of oral communication A course textbooks. SURCLE, 1, 53-60. 
